\title{
Pembelajaran Bahasa Indonesia dan Sastra (BASASTRA) di SD dan MI
}

\author{
Ummul Khair \\ Institut Agama Islam Negeri (IAIN) Curup \\ ummulkhair1213@gmail.com
}

\begin{abstract}
The learning of Bahasa Indonesia in curriculum 13 is the learning based on the text, text is an application of the thing in the human mind which is complete with the situation and context. The application of the learning uses scientific approach with suitable model. The achieving of the KD in the group KI: 1 and 2 are determine by achieving KD in the group, KI: 3 and 4 . The meaning of the language based on the function. Its mean the using of the language which is never been separated from the context because the form of the language that used represented the idea, character, values, and ideology of the user
\end{abstract}

Keywords: Indonesian language; literature; elementary school

Abstrak: Pembelajaran Bahasa Indonesis dalam kurikulum 2013 adalah pembelajaran berbasis teks. Teks merupakan ungkapan pikiran manusia yang lengkap yang di dalamnya memiliki situasi dan konteks. Pelaksanaan pembelajaran menggunakan pendekatan saintifik dengan model yang sesuai. Ketercapaian KD dalam kelompok KI: 1 dan 2 ditentukan oleh ketercapaian KD dalam kelompok KI: 3 dan 4. Bahasa hendaknya dipandang sebagai teks, bukan semata-mata kumpulan kata atau kaidah kebahasaan. Bahasa bersifat fungsional, artinya penggunaan bahasa yang tidak pernah dapat dipisahkan dari konteks, karena bentuk bahasa yang digunakan mmencerminkan ide, sikap, nilai, dan ideologi pemakai/penggunanya.

Kata kunci: Bahasa Indonesia; Sastra; SD/MI

\section{PENDAHULUAN}

Pendidikan pada dasarnya tidak dapat dipisahkan dalam kehidupan manusia. Karena dengan adanya pendidikan manusia akan mendapatkan ilmu pengetahuan. Pendidikan merupakan salah satu hal yang paling penting dalam segi pengetahuan bangsa Indonesia untuk menciptakan insan yang berilmu dan berwawasan sehingga meningkatkan kualitas sumber daya manusia yang cerdas.

AR-RIAYAH : Jurnal Pendidikan Dasar vol. 2, no. 1, 2018

STAIN Curup - Bengkulu| p ISSN 2580-362X; e ISSN 2580-3611

http://journal.staincurup.ac.id/index.php/JPD 
Selaras dengan Undang-Undang Republik Indonesia No 20 Tahun 2003 tentang Sistem Pendidikan Nasional pada bab 1 pasal 1 yang menyatakan bahwa "Pendidikan adalah usaha sadar dan terencana untuk mewujudkan suasana belajar dan proses pembelajaran agar peserta didik secara aktif mengembangkan potensi dirinya untuk memiliki kekuatan spiritual keagamaan, pengendalian diri, kepribadian, kecerdasan, akhlak mulia, serta keterampilan yang diperlukan dirinya, masyarakat, bangsa dan negara". ${ }^{1}$

Pendidikan sebagai gejala perilaku dan upaya manusia untuk memenuhi kebutuhan dasar primer bertahan hidup, bagian kegiatan untuk meningkatkan kehidupan agar lebih bermakna atau bernilai. ${ }^{2}$ Pendidikan menjadi modal utama untuk individu agar dapat mengembangkan dirinya menjadi insan yang bersikap yang memiliki akhlak mulia, berketerampilan dan berpengetahuan sesuai dengan apa yang diperlukan untuk dirinya, untuk masyarakat, untuk bangsa dan negara. Pendidikan sebagai usaha yang dijalankan oleh seseorang maupun kelompok orang agar menjadi dewasa atau mencapai tingkat hidup yang lebih tinggi.

Pembelajaran merupakan kegiatan pendidikan di sekolah yang berfungsi membantu pertumbuhan dan perkembangan anak agar tumbuh ke arah positif. Maka cara belajar siswa (subyek belajar) di sekolah diarahkan dan tidak dibiarkan berlangsung sembarangan tanpa tujuan. Melalui sistem pembelajaran di sekolah, anak melakukan kegiatan belajar dengan tujuan akan terjadi perubahan positif pada diri anak menuju kedewasaan.

Di Indonesia pendidikan formal utamanya dibagi dalam beberapa jenjang yaitu pendidikan dasar, pendidikan menengah, dan pendidikan tinggi. Pendidikan dasar mempengaruhi jenjang pendidikan menengah dan tinggi. Karena pendidikan menengah dan tinggi merupakan kelanjutan dan kesinambungan dari pendidikan dasar. Ini menjadikan pendidikan dasar sebagai acuan sebelum melangkah ke jenjang pendidikan selanjutnya. Jika pada tingkat pendidikan dasar kurang diperhatikan, kemungkinan kualitas pendidikan menjadu kurang baik.

Dalam bukunya, Muhammad Ali, menyebutkan bahwa ada 2 fungsi utama pendidikan dasar yaitu: ${ }^{3}$

1 Sisdiknas, Undang-Undang RI Nomor 20 Tahun 2003 Tentang SISDIKNAS, (Bandung: Citra Umbara, 2014), 2

${ }^{2}$ Sukardjo dan Ukim Komarudin, Landasan Pendidikan, (Depok: PT Raja Grafindo Persada, 2012), 9

${ }^{3}$ Ali Muhammad, Ilmu dan Aplikasi Pendidikan I. (Bandung: Angkasa 2009: 33), 33 
1. Pendidikan dasar memberikan dasar-dasar untuk mengikuti pendidikan pada jenjang pendidikan berikutnya. Keberhasilan mengikuti pendidikan di sekolah menengah dan perguruan tinggi banyak dipengaruhi oleh keberhasilan dalam mengikuti pendidikan dasar.

2. Jenjang pendidikan dasar di Indonesia yang biasa ada pada Sekolah dasar (SD) dan Madrasah Ibtidaiyah (MI) menjadi dasar dalam program wajib belajar 12 tahun. Program wajib belajar yang dulunya 6 tahun, diubah menjadi 9 tahun, dan kini menjadi 12 tahun merupakan kebijakan pemerintah dalam rangka meningkatkan kualitas pendidikan.

Pendidik adalah tenaga kependidikan yang berkualitas sebagai guru, dosen, konselor, pamong belajar, widyaiswara, tutor, instruktur, fasilitator dan sebutan lain yang sesuai dengan kekhususanya, serta berpartisipasi dalam menyelenggarakan pendidikan. ${ }^{4}$ Kunci berhasil atau tidaknya suatu pendidikan terletak pada seorang pendidik, karena kegiatan belajar mengajar dilakukan olehnya.

Dalam pembelajaran tugas pendidik yang paling utama adalah mengkondisikan lingkungan belajar agar dapat mendukung terjadinya perubahan perilaku yang lebih baik bagi siswa. Untuk mencapainya pendidik dapat menggunakan berbagai sumber belajar untuk mendudukung proses terjadinya perubahan tingkah laku pada siswa. Selain itu, pendidik juga harus menggunakan strategi ataupun metode pembelajaran agar siswa tertarik dan mudah memahami materi yang akan diajarkan.

Sekolah dasar (SD) sebagai penggalan pertama pendidikan dasar, seyongyanya dapat membentuk landasan yang kuat untuk tingkat pendidikan selanjutnya. Dengan tujuan sekolah harus membekali lulusannya dengan kemampuan dan keterampilan dasar yang memadai, yaitu kemampuan proses strategis.

Adapun kemampuan proses strategis adalah keterampilan berbahasa. Dengan kemampuan berbahasa yang dimiliki, siswa mampu menimba berbagai pengetahuan mengapresiasi sastra, serta mengembangkan diri secara berkelanjutan. Dengan kemampuan berbahasa yang dimiliki siswa, siswa akan mampu menimba berbagai ilmu pengetahuan yang terutama dan ditujukan dalam memahami materi bahasa Indonesia, bersastra, bahasa seni dan sastra. Dengan bahasa orang dapat: menjadi makhluk sosial berbudaya, membentuk

\footnotetext{
${ }^{4}$ Sukardjo dan Ukim Komarudin, Landasan..,hal. 3
} 
pribadi yang baik, menjadi makhluk berpribadi, menjadi warganegara, serta untuk memahami dan berpartisipasi dalam proses pembangunan masyarakat, untuk masa sekarang dan yang akan datang. Masa mendatang kita dipacu oleh kemajuan global salah satunya yang sangat nyata bidang teknologi dan informasi yang semakin canggih dengan kemampuan membaca, menulis seiring kemajuan zaman haruslah kita kembangkan secara sungguh-sungguh, agar semua kemajuan dapat kita ikuti dengan baik, benar dan tepat guna.

Bahasa Indonesia merupakan mata pelajaran yang dipelajari di sekolah dasar mulai dari kelas 1 sampai kelas 6. Pembelajaran di SD ini dapat dibagi menjadi pembelajaran kelas rendah dan kelas tinggi. Pembelajaran Bahasa Indonesia di kelas rendah memiliki kekhasan sendiri. Kekhasan ini tampak dari pendekatan pembelajaran yang menggunakan pendekatan tematik. Kekhasan juga tampak secara jelas dari materi bahan ajar yang diajarkan di SD kelas rendah.

Kekhasan pendekatan dan isi materi ajar di kelas rendah dibuat agar tujuan pengajaran bahasa Indonesia dapat tercapai yaitu 1) Siswa menghargai dan mengembangkan bahasa Indonesia sebagai bahasa persatuan (nasional) dan bahasa Negara; 2) Siswa memahami Bahasa Indonesia dari segi bentuk makna, dan fungsi, serta menggunakan dengan tepat dan kreatif untuk bermacammacam tujuan, keperluan dan keadaan; 3) Siswa memiliki kemampuan menggunakan Bahasa Indonesia untuk meningkatkan kemampuan itelektual, kematangan emosional, dan kematangan sosial; 4) Siswa memiliki disiplin dalam berpikir dan berbahasa (berbicara dan menulis); 5) Siswa mampu menikmati dan memanfaatkan karya sastra untuk mengembangkan sastra Indonesia sebagai khazanah budaya dan intelektual manusia Indonesia.

\section{LANDASAN TEORI}

Pada tahun 1996 UNESCO mencanangkan pilar-pilar penting dalam pendidikan, yakni bahwa pendidikan hendaknya mengembangkan kemampuan belajar untuk mengetahui (learning to know), belajar untuk melakukan sesuatu (learning to do), belajar menjadi seseorang (learning to be), dan belajar menjalani kehidupan bersama (learning to live together). Dalam konteks Indonesia, penerapan konsep pilar-pilar pendidikan ini adalah bahwa system pendidikan Nasional berkewajiban untuk mempersiapkan seluruh warganya agar mampu berperan 
aktif dalam semua sector kehidupan guna mewujudkan khidupan yang cerdas, aktif, kreatif, dan mengutamakan persatuan dan kesatuan. ${ }^{5}$

\section{Ciri jenjang pendidikan formal SD}
a. Tumbuh keimanan dan ketaqwaan terhadaap Tuhan Yang Maha Esa,
b. Tumbuh sikap beretika ( sopan santun dan beradab)
c. Tumbuh penalaran yang baik (mau belajar, ingin tahu, senang membaca, memiliki inovasi, berinsiatif dan bertanggungjawab):
d. Tumbuh kemampuan komunikasi/ soaial tertib, sadar aturan dapat bekerja sama dengan teman, dapat berkompetisi); dan
e. Tumbuh kesadaran untuk menjaga kesehatan badan. ${ }^{6}$

\section{Pengertian Bahasa}

Bahasa merupakan kebutuhan setiap umat manusia. Bahasa juga merupakan salah satu unsur budaya dan simbol bagi manusia dalam berkomunikasi terhadap semua kebutuhan. Melalui bahasa, manusia dapat menyampaikan atau menerima berbagai pesan, baik untuk dirinya maupun untuk orang lain. Bahasa dalam lingkup yang sangat luas tidak hanya tertuju pada bahasa lisan atau bahasa tertulis.

Bahasa merupakan alat komunikasi sosial yang berupa sistem simbol bunyi yang dihasilkan dari ucapan manusia. Manusia sebagai makhluk sosial membutuhkan sarana untuk berinteraksi dengan manusia lainnya di masyarakat. ${ }^{7}$ Untuk kepentingan interaksi sosial itu, maka dibutuhkan suatu wahana komunikasi yang disebut bahasa. Setiap masyarakat tentunya memiliki bahasa.

Secara sederhana, bahasa dapat diartikan sebagai suatu sistem lambang terorganisasi yang disepakati secara umum dan merupakan hasil belajar yang digunakan untuk menyajikan pengalamanpengalaman dalam suatu komunitas. Bahasa merupakan alat utama penyaluran kepercayaan, nilai, dan norma, termasuk seni dan religi.

Bahasa adalah alat untuk berinteraksi dengan orang lain dan sebagai alat bantu berpikir. Bahasa erat hubungannya dengan budaya mengingat bahasa erat kaitannya dengan pola pikir suatu masyarakat. Artinya, bahasa memegang peranan yang sangat penting di dalam proses berpikir dan kreativitas setiap

5 Fasli Jalil, Dedi Supriadi. Reformasi Pendidikan Dalam Konteks Otonomi Daerah, (Yogyakarta Adicita Karya Nusa,2000), 6

${ }^{6}$ Mulyasa E. Pengembangan dan Implementasi Kurikulum 2013. ( Bandung: PT. Remaja Rosdakarya, 2013 ), 21

${ }^{7}$ Goris Keraf. Komposisi : Sebuah Pengantar Kemabiran Babasa.(Jakata: Flores: Nusa Indah. 1997), 11 
individu. Bahasa bersifat simbolis, artinya suatu kata mampu melambangkan arti apapun. Melalui bahasa terjadi pewarisan budaya dari satu generasi ke generasi selanjutnya. Misalnya, seorang pelukis di pantai panjang Bengkulu membimbing muridnya cara melukis bungg Raflesia dengan menggunakan bahasa Bengkulu. Seorang guru bahasa daerah seperto bahasa kagannga di daerah Curup akan mengajarakn siswa nya menggunakan bahasa kagangga. Begitu juga, para ustads di MDA akan mengajarkan muridanya seni membaca al Quran dengan bahasa Arab dan bahasa daerah setempat.

\section{Peranan bahasa Indonesia \\ a. Sebagai Bahasa Nasional}

Sebagai lambang kebanggaan dan identitas nasional, Bahasa persatuan kita, memiliki nilai-nilai sosial budaya luhur bangsa yang harus dipertahankan dan direalisasikan dalam kehidupan sehari-hari tanpa ada rasa renda diri, malu, dan acuh tak acuh. Indonesia memiliki banyak budaya dan bahasa yang berbeda-beda hampir di setiap daerah. Pastinya, tidak akan mungkin kita bisa saling memahami ketika berkomunikasi antar sesama. Oleh karena itulah betapa pentingnya kedudukan bahasa indonesia sebagai bahasa pemersatu bangsa dan sebagai alat penghubungan antarbudaya dan daerah.

\section{b. Sebagai Bahasa Negara}

Dalam "Hasil Perumusan Seminar Politik Bahasa Nasional" yang diselenggarakandi Jakarta pada tanggal 25 s.d. 28 Februari 1975 dikemukakan bahwa di dalam kedudukannya sebagai bahasa negara, bahasa Indonesia memiliki fungsi sebagai : bahasa dalam perhubungan pada tingkat nasional untuk kepentinganperencanaan dan pelaksanaan pembangunan serta menjadi bahasa resmi kenegaraan, pengantar di lembaga-lembaga pendidikan/ pemanfaatan ilmu pengetahuan, pengembangan kebudayaan, pemerintah dll.

\section{c. Sebagai Alat Untuk Mengembangkan Ilmu Pengetahuan}

Menurut Sunaryo tanpa adanya bahasa (termasuk bahasa Indonesia) IPTEK tidak dapat tumbuh dan berkembang. Selain itu bahasa Indonesia di dalam struktur budaya, ternyata memiliki kedudukan, fungsi, dan peran ganda, yaitu sebagai akar dan produk budaya yang sekaligus berfungsi sebagai sarana berpikir dan sarana pendukung pertumbuhan dan perkembangan ilmu pengetahuan dan teknologi. Tanpa peran bahasa serupa itu, ilmu pengetahuan dan teknologi tidak akan dapat berkembang. Implikasinya di dalam pengembangan daya nalar, menjadikan bahasa sebagai prasarana berpikir 
modern. Oleh karena itu, jika cermat dalam menggunakan bahasa, kita akan cermat pula dalam berpikir karena bahasa merupakan cermin dari daya nalar (pikiran). ${ }^{8}$

Bahasa Indonesia juga digunakan sebagai alat pengembangan kebudayaan nasional, ilmu pengetahuan dan teknologi. Bahasa Indonesia merupakan alat yang digunakan sebagai bahasa media massa untuk menunjang perkembangan ilmu pengetahuan dan teknologi. Bahasa Indonesia yang benar adalah bahasa yang menerapkan kaidah dengan konsisten. Sedangkan bahasa yang baik adalah bahasa yang mempunyai nilai rasa yang tepat dan sesuai dengan situasi pemakaiannnya. Penggunaan bahasa Indonesia yang baik dan benar akan menghasilkan pemikiran yang baik dan benar pula. Kenyataan bahwa bahasa Indonesia sebagai wujud identitas bahasa Indonesia menjadi sarana komunikasi di dalam masyarakat modern.

Bahasa Indonesia bersikap terbuka sehingga mampu mengembangkan dan menjalankan fungsinya sebagai sarana komunikasi masyarakat modern. Semakin berkembangnya teknologi di dalam kehidupan kita akan berdampak juga pada perkembangan dan pertumbuhan bahasa sebagai sarana pendukung pertumbuhan dan perkembangan budaya, ilmu pengetahuan dan teknologi. Di zaman era globalisasi itu, bangsa Indonesia harus ikut berperan di dalam dunia persaingan bebas, baik di bidang politik, ekonomi, maupun komunikasi. Konsep-konsep dan istilah baru di dalam pertumbuhan dan perkembangan ilmu pengetahuan dan teknologi (IPTEK) secara tidak langsung memperkaya khasanah bahasa Indonesia. Dengan demikian, semua produk budaya akan tumbuh dan berkembang pula sesuai dengan pertumbuhan dan perkembangan ilmu pengetahuan dan teknologi itu, termasuk bahasa Indonesia, sekaligus berperan sebagai prasarana berpikir dan sarana pendukung pertumbuhan dan perkembangan IPTEK.

\section{Tujuan Pengajaran}

Suatu kegiatan tentulah memiliki suatu tujuan yang hendak dicapai, dan untuk mewujudkan tujuan tersebut memerlukan pengorbanan, usaha yang maksimal dengan segala kemampuan yang ada. Keberhasilan dari tujuan yang hendak dicapai dalam suatu kegiatan tergantung dengan kesungguh-sungguhan pelaku kegiatan dalam menjalankan kegiatan tersebut untuk mencapai tujuan

$$
\text { 2000), } 6
$$

${ }^{8}$ Sunaryo Kartadinata. Panduan Pengajar Buku Inovasi Pendidikan, Jakarta,. Depdikbud. 
yang dikehendaki. Begitu juga dengan suatu pengajaran di sekolah sangat mempunyai tujuan yang akan dicapai.

Dalam dunia pendidikan pun segala kegiatan yang dilakukan pasti mempunyai suatu tujuan yakni melakukan suatu perubahan-perubahan yang pasti kearah kemajuan, kearah perbaikan. Sardima AM mengatakan bahwa tujuan dalam dunia pendidikan dapat diartikan sebagai suatu usaha untuk memberikan rumusan hasil yang diharapkan dari siswa/ subyek belajar, setelah menyelesaikan/ memperoleh pengalaman belajar. Winarno Surakhmad seperti yang dikutip Sardiman AM memberikan keterangan bahwa rumusan dan taraf pencapaian tujuan pengajaran adalah merupakan petujuk praktis tentang sejauh manakah interaksi edukatif itu harus dibawa untuk mencapai tujuan akhir.

Dengan demikian tujuan itu sesuatu yang diharapkan/ diinginkan dari subyek belajar, sehingga memberi arah, kemana kegiatan belajar-mengajar itu harus dibawa dan dilaksanakan. Tujuan pembelajaran harus dirumuskan karena akan membantu mempermudah guru dalam mendisain program dan kegiatan pengajaran, memudahkan pengawasan dan penilaian hasil belajar sesuai yang diharapkan dan memberikan pedoman bagi siswa dalam menyelesaikan materi dan kegiatan belajar.

\section{Kurikulum K-13}

Pengesahan kurikulum 2013 merupakan penyempurnaan dari kurikulum sebelumnya, yakni Kurikulum 2006 atau KTSP (Kurikulum Tingkat Satuan Pendidikan) telah membawa perubahan yang mendasar dalam pembelajaran Bahasa Indonesia. Pada Kurikulum 2006, mata pelajaran Bahasa Indonesia lebih mengedepankan pada keterampilan berbahasa (dan bersastra), sedangkan dalam Kurikulum 2013, Pembelajaran Bahasa Indonesia digunakan sebagai sarana untuk mengembangkan kemampuan dan keterampilan menalar. Perubahan ini terjadi dilatarbelakangi oleh kenyataan bahwa kemampuan menalar peserta didik Indonesia masih sangat rendah. Hal ini diketahui dari studi Trends in International Mathematics and Science Study (TIMSS) tahun 2011, hanya lima persen peserta didik Indonesia yang mampu memecahkan persoalan yang membutuhkan pemikiran, sedangkan sisanya 95 persen, hanya sampai pada level menengah, yaitu memecahkan persoalan yang bersifat hapalan. Ini membuktikan, bahwa pendidikan Indonesia baru berada pada tatanan konseptual. Untuk itu, pembelajaran bahasa Indonesia merupakan salah satu

\section{${ }^{9}$ Ibid.., 7}


solusi, yaitu dengan menjadikan bahasa sebagai penghela ilmu pengetahuan dan pembelajaran berbasis teks.

Adanya Perubahan dalam pembelajaran bahasa Indonesia tersebut seyogiaya diiringi dengan kompetensi guru dalam mengimplementasikan pembelajaran bahasa dengan pradigma baru yaitu pembelajaran berbasis "Teks". Untuk itu, dalam paparan ini akan menyigi Pembelajaran Bahasa Indonesia dalam Kurikulum 2013 sebagai Kajian dalam Mata Diklat Penerapan Kurikulum 2013. Dengan perubahan kurikulum pembelajaran maka impleentasi pembelajaran bahasa Indonesia berbasis teks dalam kurikulum K13.

\section{Pembelajaran Bahasa Indonesia dalam Kurikulum 2013}

Pembelajaran bahasa indonesia disuguhakan pada peserta didik bertujuan untuk melatih peserta didik terampil berbahasa dengan menuangkan ide dan gagasanya secara kreatif dan kritis. Namun kenyataannya banyak guru terjebak dalam tatanan konsep sehingga pembelajaran cenderung membahas teori-teori bahasa. Sebagaimana yang dikemukakan Slamet, bahwa pengajaran bahasa Indonesia adalah pengajaran keterampilan berbahasa bukan pengajaran tentang kebahasaan. Teori-teori bahasa hanya sebagai pendukung atau penjelas dalam konteks, yaitu yang berkaitan dengan keterampilan tertentu yang tengah diajarkan

\section{Pembelajaran Bahasa Indonesia}

Pembelajaran bahasa Indonesia pada hakikatnya adalah membelajarkan peserta didik tentang keterampilan berbahasa Indonesia yang baik dan benar sesuai tujuan dan fungsinya. Menurut Atmazaki, mata pelajaran Bahasa Indonesia bertujuan agar peserta didik memiliki kemampuan berkomunikasi secara efektif dan efisien sesuai dengan etika yang berlaku, baik secara lisan maupun tulis, menghargai dan bangga menggunakan bahasaIndonesia sebagai bahasa persatuan dan bahasa negara, memahami bahasa Indonesia dan menggunakannya dengan tepat dan kreatif untuk berbagai tujuan, menggunakan bahasa Indonesia untuk meningkatkan kemampuan intelektual, serta kematangan emosional dan sosial, menikmati dan memanfaatkan karya sastra untuk memperluas wawasan, budi pekerti, serta meningkatkan pengetahuan dan kemampuan berbahasa, dan menghargai dan membanggakan sastra Indonesia sebagai khazanah budaya dan intelektual manusia Indonesia. ${ }^{10}$

${ }^{10}$ Nasution, S., 1999, Kurikulum dan Pengajaran, Jakarta: Bumi Aksara, cet-ke-3, 23 
Untuk mengimplementasikan tujuan mata pelajaran Bahasa Indonesia tersebut, maka pembelajaran bahasa Indonesia dalam kurikulum 2013 disajikan dengan menggunakan pendekatan berbasis teks. Teks dapat berwujud teks tertulis maupun teks lisan. Teks merupakan ungkapan pikiran manusia yang lengkap yang di dalamnya memiliki situasi dan konteks. Dengan kata lain, belajar Bahasa Indonesia tidak sekadar memakai bahasa Indonesia sebagai alat komunikasi, tetapi perlu juga mengetahui makna atau bagaimana memilih kata yang tepat yang sesuai tatanan budaya dan masyarakat pemakainya. ${ }^{11}$

Mahsun, menyatakan, dalam pembelajaran Bahasa ada dua komponen yang harus dipelajarai, yaitu masalah makna dan bentuk. Kedua unsur tersebut harus hadir secara stimulant dan keduanya harus ada. Namun pemakai bahasa harus menyadari bahwa komponen makna menjadi unsur utama dalam pembentuk bahasa, dan karena itu bahasa menjadi sarana pembentukan pikiran manusia. Untuk itu guru perlu menyadari, bahwa kemampuan berpikir yang harusnya dibentuk dalam bahasa adalah kemampuan berpikir sistematis, terkontrol, empiris, dan kritis. Secara stipulatif kemampuan berpikir tersebut disebut dengan berpikir metodologis yang hanya dapat dicapai melalui pembelajaran teks berdasarkan pendekatan ilmiah/ saintifik. ${ }^{12}$

Pada kesempatan lain Mahsun, menyatakan, kehadiran konteks budaya, selain konteks situasi yang melatarbelakangi lahirnya suatu teks menunjukkan adanya kesejajaran antara pembelajaran berbasis teks (konsep bahasa) dengan filosofi pengembangan Kurikulum 2013. Khusus yang terkait dengan rumusan kebutuhan kompetensi peserta didik dalam bentuk kompetensi inti (KI) atas domein sikap, pengetahuan, dan keterampilan (sebagai penguatan dapat dilihat dalam Standar Isi Permen dikbud Tabun 2014). Kompetensi inti yang menyangkut sikap, baik sikap spiritual (KI: 1 ) maupun sikap sosial (KI: 2) terkait dengan konsep kebahasaan tentang nilai, norma kultural, serta konteks sosial yang menjadi dasar terbentuknya register (bahasa sebagai teks); kompetensi inti yang menyangkut pengetahuan (KI: 3) dan keterampilan (KI: 4) terkait langsung dengan konsep kebahasaan yang berhubungan dengan proses sosial (genre) dan register (bahasa sebagai teks). Selain itu, antarkompetensi dasar (KD) yang dikelompokkan berdasarkan KI tersebut memiliki hubungan pendasaran satu sama lain. Ketercapaian KD dalam kelompok KI: 1 dan 2 ditentukan oleh

\footnotetext{
${ }^{11}$ Ibid.., 24

${ }^{12}$ Mahsun. 2014. Teks Pembelajaran Bahasa Indonesia Kurikulum 2013. Jakarta:
} Raja Grafindo Persada, 39 
ketercapaian KD dalam kelompok KI: 3 dan 4. KD dalam kelompok KI: 1 dan 2 bukan untuk diajarkan melainkan implikasi dari ketercapaian KD dalam kelompok KI: 3 dan $4 .{ }^{13 .}$

Pencapaian kompetensi tersebut berkaitan erat dengan proses pembelajaran yang dilaksanakan. Untuk itu, guru harus merencanakan pembelajaran sesuai tuntutan kurikulum dengan menggunakan pendekatan saintifik dan model pembelajaran yang mendorong kemampuan peserta didik untuk melakukan penyingkapan/penelitian, serta dapat menghasilkan karya kontekstual, baik individual maupun kelompok.

Dengan memahami keterkaitan masing-masing kompetensi dalam pembelajaran, khusunya pembelajaran bahasa Indonesia dengan pembelajaran berbasis teks akan mampu mengembangkan kemampuan berpikir peserta didik secara kreatif dan kritis. Di samping itu, pembelajaran Bahasa Indonesia dapat berperan sebagai penghela dan pengintegrasi ilmu lain.

\section{Pembelajaran Bahasa Indonesia dalam Kurikulum 2013}

Pembelajaran Bahasa Indonesia yang terdapat dalam kurikulum 2013 dengan pembelajaran berbasis teks bertujuan agar dapat membawa peserta didik sesuai perkembangan mentalnya, dan menyelesaikan masalah kehidupan nyata dengan berpikir kritis. Dalam penerapannya, pembelajaran Bahasa Indonesia memiliki prinsip, yaitu sebagai berikut.

a. Bahasa hendaknya dipandang sebagai teks, bukan semata-mata kumpulan kata atau kaidah kebahasaan.

b. Penggunaan bahasa merupakan proses pemilihan bentuk-bentuk kebahasan untuk mengungkapkan makna.

c. Bahasa bersifat fungsional, artinya penggunaan bahasa yang tidak pernah dapat dipisahkan dari konteks, karena bentuk bahasa yang digunakan mencerminkan ide, sikap, nilai, dan ideologi pemakai/penggunanya.

d. Bahasa merupakan sarana pembentukan berpikir manusia.

Dengan prinsip di atas, maka pembelajaran bahasa berbasis teks membawa implikasi metodologis pada pembelajaran yang bertahap. Hal ini diawali dari kegiatan guru membangun konteks, dilanjutkan dengan kegiatan pemodelan, membangun teks secara bersama-sama, sampai pada membangun teks secara mandiri. Kegiatan ini dilakukan karena teks merupakan satuan bahasa yang mengandung pikiran dengan struktur yang lengkap. Guru harus

${ }^{13}$ Mahsun. 2014. Teks Pembelajaran.., 40 
benar-benar meyakini bahwa pada akhirnya peserta didik mampu menyajikan teks secara mandiri. Secara rinci tahapan tersebut sebagai berikut.

\section{Membangun konteks}

Membangun kontek, yaitu melalui kegiatan mengamati teks dalam konteksnya dan menanya tentang berbagai hal yang berkaitan dengan teks yang diamatinya. Pada langkah membangun konteks peserta didik dapat didorong untuk memahami nilai spiritual, nilai budaya, tujuan yang melatari bangun teks. Dalam proses ini peserta didik mengeksplorasi kandungan teks serta nilai-nilai yang tersirat di dalamnya. Di samping itu, peserta didik dapat mengungkap laporan hasil pengamatan untuk bahan tindak lanjut dalam kegiatan belajar.

\section{Membentuk model (Pemodelan)}

Pemodelan, yaitu melalui kegiatan mencoba dan menalar merumuskan model strukur fonologi, gramatikal, leksikal, dan makna teks dibacanya. Dalam langkah ini peserta didik didorong untuk meningkatkan rasa ingin tahu dengan memperhatikan (1) simbol, (2) bunyi (3) tata bahasa dan (4) makna. Melalui analisis fakta dan data pada teks yang dipelajarinya peserta didik memperoleh model imbuhan, struktur imkata, frase, klausa, kalimat, maupun paragraf. Semua kegiatan tersebut peserta didik pelajari pada konteks pemakaiannya. Pada tahapan ini peserta didik dapat mengeksplorasi jenis teks yang dipelajarinya serta mengenali ciri-cirinya. Proses aktivitas pengenalan bukan sebagai tujuan akhir pembelajaran, melainkan sebagai awal kegiatan untuk mengembangkan daya cipta.

\section{Membangun teks bersama-sama}

Membangun teks bersama/berkelompok, yaitu menyusun teks bersama masih dalam kegiatan mencoba, menalar, dan mencipta secara kolaboratif yang dilanjutkan dengan menyaji. Peserta menggunakan hasil mengeksplorasi modelmodel teks untuk membangun teks dengan cara berkolaborasi dalam kelompok. Melalui kegiatan ini diharapkan semua peserta didik dapat memperoleh pengalaman mencipta teks sebagai dasar untuk mengembangkan kompetensi individu.

\section{Mengembangkan teks secara mandiri}

Mengembangkan teks secara mandiri, yaitu dengan titik tekan pada peserta didik dapat menunjukkan kompetensinya secara individual dalam mencipta. Oleh karena itu, dimensi kegiatan pembelajaran bahasa Indonesia 
wajib memenuhi empat langkah dasar, enam langkah mengembangkan keterampilan beraktivitas secara saintifik, dua model kegiatan koloboratif dan individual, dan berdimesi beraktivitas dan berkarya.

Untuk implemetasi dalam pembelajaran, guru dapat menggunakan model pembelajaran, antara lain model inkuiri based learning, discovery based learning, problem based learning, danproject based learning. Model-model tersebut masing-masing memiliki langkah kerja yang sistematis dalam penerapannya. Dalam penerapan model tidak ada satu model yang unggul dari model lain, namun guru perlu mencocokkan dengan lingkup materi dan strategi pembelajaran yang digunakan.

\section{Kompetensi Inti}

Kompetensi Inti Sekolah Dasar/Madrasah Ibtidaiyah (SD/MI) merupakan tingkat kemampuan untuk mencapai Standar Kompetensi Lulusan (SKL) yang harus dimiliki seorang peserta didik SD/MI pada setiap tingkat kelas. Kompetensi Inti dirancang untuk setiap kelas/usia tertentu. Melalui Kompetensi Inti, sinkronisasi horisontal berbagai Kompetensi Dasar antar matapelajaran pada kelas yang sama dapat dijaga. Selain itu sinkronisasi vertikal berbagai Kompetensi Dasar pada mata pelajaran yang sama pada kelas yang berbeda dapat dijaga pula.

Rumusan Kompetensi Inti menggunakan notasi sebagai berikut:

1. Kompetensi Inti-1 (KI-1) untuk Kompetensi Inti sikap spiritual;

2. Kompetensi Inti-2 (KI-2) untuk Kompetensi Inti sikap sosial;

3. Kompetensi Inti-3 (KI-3) untuk Kompetensi Inti pengetahuan; dan

4. Kompetensi Inti-4 (KI-4) untuk Kompetensi Inti keterampilan.

Uraian tentang Kompetensi Inti untuk jenjang SD/MI dapat dilihat pada Tabel berikut : ${ }^{14}$

\section{Tabel 1 : Kompetensi Inti SD/MI Kelas I, II, dan III}

\begin{tabular}{|c|c|c|}
\hline $\begin{array}{c}\text { Kompetensi Inti } \\
\text { Kelas I }\end{array}$ & $\begin{array}{c}\text { Kompetensi Inti } \\
\text { Kelas II }\end{array}$ & $\begin{array}{c}\text { Kompetensi Inti } \\
\text { Kelas III }\end{array}$ \\
\hline $\begin{array}{l}\text { 1. Menerima dan } \\
\text { menjalankan } \\
\text { ajaran agama yang } \\
\text { dianutnya }\end{array}$ & $\begin{array}{l}\text { 1. Menerima dan } \\
\text { menjalankan ajaran } \\
\text { agama yang } \\
\text { dianutnya }\end{array}$ & $\begin{array}{l}\text { 1. Menerima dan } \\
\text { menjalankan ajaran } \\
\text { agama yang } \\
\text { dianutnya }\end{array}$ \\
\hline
\end{tabular}

${ }^{14}$ Mulyasa E. Pengembangan dan Implementasi Kurikulum 2013. ( Banung: PT. Remaja Rosdakarya, 2013 ), 173 


\begin{tabular}{|c|c|c|c|c|}
\hline 2. & $\begin{array}{l}\text { Memiliki perilaku } \\
\text { jujur, disiplin, } \\
\text { tanggung jawab, } \\
\text { santun, peduli, } \\
\text { dan percaya diri } \\
\text { dalam berinteraksi } \\
\text { dengan keluarga, } \\
\text { teman, dan guru. }\end{array}$ & 2. & $\begin{array}{l}\text { Menunjukkan } \\
\text { perilaku jujur, } \\
\text { disiplin, tanggung } \\
\text { jawab, santun, } \\
\text { peduli, dan percaya } \\
\text { diri dalam } \\
\text { berinteraksi dengan } \\
\text { keluarga, teman, } \\
\text { dan guru. }\end{array}$ & $\begin{array}{l}\text { 2. Menunjukkan } \\
\text { perilaku jujur, } \\
\text { disiplin, tanggung } \\
\text { jawab, santun, peduli, } \\
\text { dan percaya diri } \\
\text { dalam berinteraksi } \\
\text { dengan keluarga, } \\
\text { teman, guru dan } \\
\text { tetangganya }\end{array}$ \\
\hline 3. & $\begin{array}{l}\text { Memahami } \\
\text { pengetahuan } \\
\text { faktual dengan } \\
\text { cara mengamati } \\
\text { [mendengar, } \\
\text { melihat, } \\
\text { membaca] dan } \\
\text { menanya } \\
\text { berdasarkan rasa } \\
\text { ingin tahu tentang } \\
\text { dirinya, makhluk } \\
\text { ciptaan Tuhan dan } \\
\text { kegiatannya, dan } \\
\text { benda-benda yang } \\
\text { dijumpainya di } \\
\text { rumah dan di } \\
\text { sekolah. }\end{array}$ & 3. & $\begin{array}{l}\text { Memahami } \\
\text { pengetahuan faktual } \\
\text { dengan cara } \\
\text { mengamati } \\
\text { [mendengar, } \\
\text { melihat, membaca] } \\
\text { dan menanya } \\
\text { berdasarkan rasa } \\
\text { ingin tahu tentang } \\
\text { dirinya, makhluk } \\
\text { ciptaan Tuhan dan } \\
\text { kegiatannya, dan } \\
\text { benda-benda yang } \\
\text { dijumpainya di } \\
\text { rumah dan di } \\
\text { sekolah }\end{array}$ & $\begin{array}{l}\text { 3. Memahami } \\
\text { pengetahuan faktual } \\
\text { dengan cara mengamati } \\
\text { [mendengar, melihat, } \\
\text { membaca] dan menanya } \\
\text { berdasarkan rasa ingin } \\
\text { tahu tentang dirinya, } \\
\text { makhluk ciptaan Tuhan } \\
\text { dan kegiatannya, dan } \\
\text { benda-benda yang } \\
\text { dijumpainya di rumah } \\
\text { dan di sekolah }\end{array}$ \\
\hline 4. & $\begin{array}{l}\text { Menyajikan } \\
\text { pengetahuan } \\
\text { faktual dalam } \\
\text { bahasa yang jelas } \\
\text { dan logis, dalam } \\
\text { karya yang estetis, } \\
\text { dalam gerakan } \\
\text { yang } \\
\text { mencerminkan } \\
\text { anak sehat, dan } \\
\text { dalam tindakan } \\
\text { yang } \\
\text { mencerminkan } \\
\text { perilaku anak } \\
\text { beriman dan } \\
\text { berakhlak mulia }\end{array}$ & 4. & $\begin{array}{l}\text { Menyajikan } \\
\text { pengetahuan faktual } \\
\text { dalam bahasa yang } \\
\text { jelas dan logis, } \\
\text { dalam karya yang } \\
\text { estetis, dalam } \\
\text { gerakan yang } \\
\text { mencerminkan anak } \\
\text { sehat, dan dalam } \\
\text { tindakan yang } \\
\text { mencerminkan } \\
\text { perilaku anak } \\
\text { beriman dan } \\
\text { berakhlak mulia }\end{array}$ & $\begin{array}{l}\text { 4. Menyajikan } \\
\text { pengetahuan faktual } \\
\text { dalam bahasa yang } \\
\text { jelas, sistematis dan } \\
\text { logis, dalam karya } \\
\text { yang estetis, dalam } \\
\text { gerakan yang } \\
\text { mencerminkan anak } \\
\text { sehat, dan dalam } \\
\text { tindakan yang } \\
\text { mencerminkan } \\
\text { perilaku anak } \\
\text { beriman dan } \\
\text { berakhlak mulia }\end{array}$ \\
\hline
\end{tabular}




\section{Tabel 2 : Kompetensi Inti SD/MI Kelas IV, V, dan VI}

\begin{tabular}{|c|c|c|}
\hline $\begin{array}{c}\text { Kompetensi Inti } \\
\text { Kelas IV }\end{array}$ & $\begin{array}{c}\text { Kompetensi Inti } \\
\text { Kelas V }\end{array}$ & $\begin{array}{c}\text { Kompetensi Inti } \\
\text { Kelas VI }\end{array}$ \\
\hline $\begin{array}{l}\text { 1. Menerima, } \\
\text { menjalankan, dan } \\
\text { menghargai ajaran } \\
\text { agama yang } \\
\text { dianutnya }\end{array}$ & $\begin{array}{l}\text { 1. Menerima, } \\
\text { menjalankan, dan } \\
\text { menghargai ajaran } \\
\text { agama yang } \\
\text { dianutnya. }\end{array}$ & $\begin{array}{l}\text { 1. Menerima, } \\
\text { menjalankan, dan } \\
\text { menghargai ajaran } \\
\text { agama yang } \\
\text { dianutnya. }\end{array}$ \\
\hline $\begin{array}{l}\text { 2. Menunjukkan } \\
\text { perilaku jujur, } \\
\text { disiplin, tanggung } \\
\text { jawab, santun, } \\
\text { peduli, dan } \\
\text { percaya diri dalam } \\
\text { berinteraksi } \\
\text { dengan keluarga, } \\
\text { teman, guru, dan } \\
\text { tetangganya } \\
\end{array}$ & $\begin{array}{l}\text { 2. Menunjukkanperilak } \\
\text { u jujur, disiplin, } \\
\text { tanggung jawab, } \\
\text { santun, peduli, dan } \\
\text { percaya diri dalam } \\
\text { berinteraksi dengan } \\
\text { keluarga, teman, } \\
\text { guru, dan } \\
\text { tetangganya serta } \\
\text { cinta tanah air. } \\
\end{array}$ & $\begin{array}{l}\text { 2. Menunjukkan perilaku } \\
\text { jujur, disiplin, } \\
\text { tanggung jawab, } \\
\text { santun, peduli, dan } \\
\text { percaya diri } \\
\text { dalamberinteraksi } \\
\text { dengan keluarga, } \\
\text { teman, guru, dan } \\
\text { tetangganya serta } \\
\text { cinta tanah air. } \\
\end{array}$ \\
\hline $\begin{array}{l}\text { 3. Memahami } \\
\text { pengetahuan } \\
\text { faktual dengan } \\
\text { cara mengamati } \\
\text { dan menanya } \\
\text { berdasarkan rasa } \\
\text { ingin tahu tentang } \\
\text { dirinya, makhluk } \\
\text { ciptaan Tuhan dan } \\
\text { kegiatannya, dan } \\
\text { benda-benda yang } \\
\text { dijumpainya di } \\
\text { rumah, di sekolah } \\
\text { dan tempat } \\
\text { bermain. }\end{array}$ & $\begin{array}{l}\text { 3. Memahami } \\
\text { pengetahuan faktual } \\
\text { dan konseptual } \\
\text { dengan cara } \\
\text { mengamati, } \\
\text { menanya dan } \\
\text { mencoba } \\
\text { berdasarkan rasa } \\
\text { ingin tentang } \\
\text { dirinya, makhluk } \\
\text { ciptaan Tuhan dan } \\
\text { kegiatannya, dan } \\
\text { benda-benda yang } \\
\text { dijumpainya di } \\
\text { rumah, di sekolah } \\
\text { dan tempat } \\
\text { bermain. }\end{array}$ & $\begin{array}{l}\text { 3. Memahami } \\
\text { pengetahuan faktual } \\
\text { dan konseptual } \\
\text { dengan cara } \\
\text { mengamati, menanya } \\
\text { dan mencoba } \\
\text { berdasarkan rasa ingin } \\
\text { tahu tentang dirinya, } \\
\text { makhluk ciptaan } \\
\text { Tuhan dan } \\
\text { kegiatannya, dan } \\
\text { benda-benda yang } \\
\text { dijumpainya di rumah, } \\
\text { di sekolah dan tempat } \\
\text { bermain }\end{array}$ \\
\hline
\end{tabular}




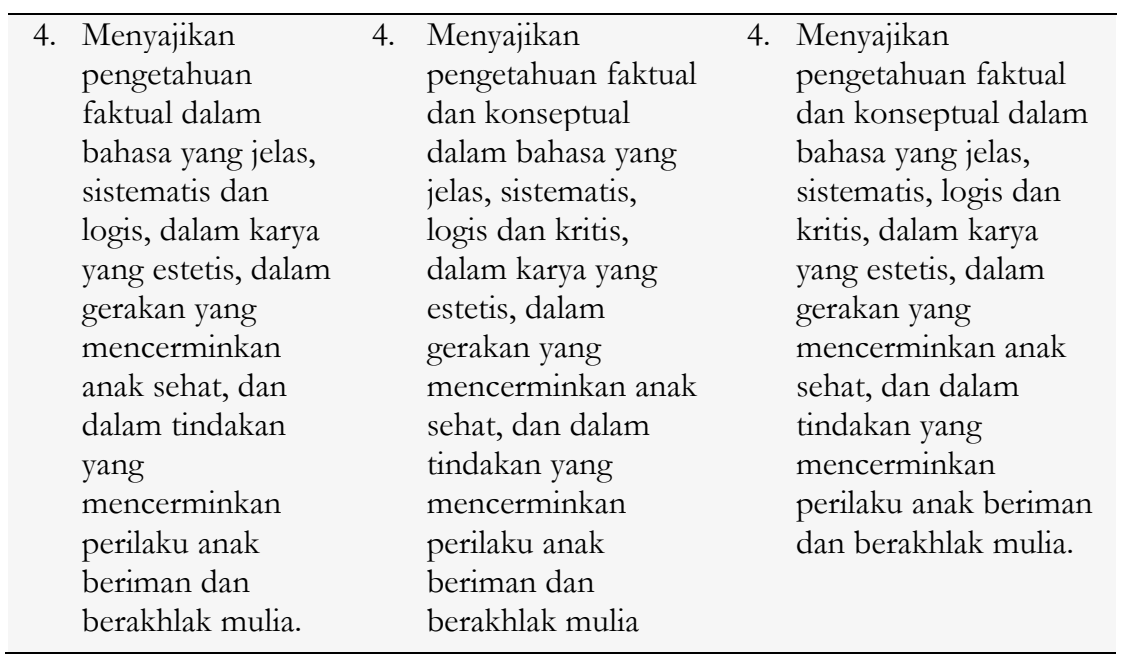

\section{Kompetensi Dasar}

Kompetensi Dasar dirumuskan untuk mencapai Kompetensi Inti. Rumusan Kompetensi Dasar dikembangkan dengan memperhatikan karakteristik dan kemampuan peserta didik, dan kekhasan masingmasing mata pelajaran. Kompetensi Dasar meliputi empat kelompok sesuai dengan pengelompokan Kompetensi Inti sebagai berikut:

1. kelompok 1 : kelompok Kompetensi Dasar sikap spiritual dalam rangka menjabarkan KI1;

2. kelompok 2 : kelompok Kompetensi Dasar sikap sosial dalam rangka menjabarkan $\mathrm{KI} 2$;

3. kelompok 3 : kelompok Kompetensi Dasar pengetahuan dalam rangka menjabarkan $\mathrm{KI} 3$; dan

4. kelompok 4 : kelompok Kompetensi Dasar keterampilan dalam rangka menjabarkan KI4.

Pembelajaran bahasa Indonesia pada kurikulum 2013 bermuara pada pengembangan kompetensi dalam ranah sikap (KI-1 dan KI-2), pengetahuan (KI-3), dan (KI-4) keterampilan. Pendekatan berbasis teks yang dikembangkan pada kurikulum ini diaplikasikan melalui KBM yang mendorong peserta didik untuk mengembangkan pengetahuan (KI-3) dan keterampilan (KI-4) mereka dalam memahami dan menyusun berbagai jenis teks sesuai dengan jenjang. Pengembangan sikap (KI-1 dan KI-2) tidak menjadi bagian tersendiri sebagai sesuatu yang diajarkan dalam proses pembelajaran. 
Kompetensi dasar yang terdapat pada KI-1 dan KI-2 dikembangkan melalui integrasi dalam pengembangan kompetensi pengetahuan dan keterampilan. Sebagai contoh, ketika peserta didik mempelajari struktur teks laporan observasi dan mengaplikasikan konsep tersebut melalui penyusunan teks, sikap-sikap yang diinginkan pada KD di KI-2, yaitu disiplin, tanggung jawab, dan kerja keras. Guru harus selalu terus menerus mengembangkan sikapsikap ini di dalam KBM.

Kurikulum 2013 lebih menekankan pada pembentukan sikap/afektif. Untuk pembentukan sikap ini, hanya aspek-aspek seni yang mampu menjangkaunya. Sikap hanya akan terjangkau dengan seni matematika, seni kimia, seni fisika, dan seterusnya. Nah, karena itu aspek sastra menjadi sesuatu yang mutlak disuguhkan kepada generasi melalui pendidikan di kelas. Kehadiran kurikulum baru yang pro- dan kontra- ini ternyata memberikan peluang tersendiri bagi konten sastra. Meskipun tidak semua (juga tidak mungkin untuk semua) konten pembelajaran bahasa Indonesia adalah sastra, tetapi peluang konten pembelajaran sastra memiliki ruang yang luas. Artinya, setiap kompetensi dasarnya sangat memungkinkan diajarkan dengan sastra sebagai dasarnya.

\section{SIMPULAN}

Di sekolah dasar pembelajaran bahasa dan sastra Indonesia lebih diarahkan pada kompetensi siswa untuk berbahasa dan berapresiasi sastra. Pelaksanaannya, pembelajaran sastra dan bahasa dilaksanakan secara terintegrasi. Sedangkan pengajaran sastra, ditujukan untuk meningkatkan kemampuan siswa dalam menikmati, menghayati, dan memahami karya sastra. Pengetahuan tentang sastra hanyalah sebagai penunjang dalam mengapresiasi.

\section{DAFTAR PUSTAKA}

Ali Muhammad, Ilmu dan Aplikasi Pendidikan I. (Bandung: Angkasa 2009: 33).

Atmazaki. 2013. Mengungkap Masa Depan: Inovasi Pembelajaran Bahasa Indonesia dalam Konteks Pengembangan Karakter Cerdas. Makalah. Padang: UNP.

Fasli Jalil, Dedi Supriadi, Reformasi Pendidikan Dalam Konteks Otonomi Daerah, (Yogyakarta Adicita Karya Nusa, 2000).

Kartadinata Sunaryo. Panduan Pengajar Buku Inovasi Pendidikan, Jakarta, Depdikbud. 2000). 
98 | AR-RIAYAH : Jurnal Pendidikan Dasar vol. 2, no. 1, 2018

Keraf. Komposisi : Sebuah Pengantar Kemahiran Bahasa.(Jakata: Flores: Nusa Indah. 1997)

Mahsun. 2014. Teks Pembelajaran Bahasa Indonesia Kurikulum 2013. Jakarta: Raja Grafindo Persada.

Mulyasa E. Pengembangan dan Implementasi Kurikulum 2013. ( Bandung: PT. Remaja Rosdakarya, 2013 ).

Nasution, S., 1999, Kurikulum dan Pengajaran, Jakarta: Bumi Aksara, cet-ke-3

Sardiman A.M,. Interaksi \& Motivasi Belajar Mengajar. (Jakarta: Rajawali Pers. $2000)$.

Slamet. Dasar-dasar Pembelajaran Bahasa dan Sastra Indonesia di Sekolah Dasar (Jakarat: Lembaga Pengembangan Pendidikan (LPP) UNS dan UPT Penerbitan dan Percetakan UNS (UNS Pres.: 2007 ).

Sukardjo dan Ukim Komarudin, Landasan Pendidikan, (Depok: PT Raja Grafindo Persada, 2012).

Undang-Undang RI Nomor 20 Tahun 2003 Tentang SISDIKNAS, (Bandung: Citra Umbara, 2014). 